\title{
Model of Entry on a Foreign Market and the Characteristics of the Assortment Offer of Furniture Exporters from Bosnia and Herzegovina
}

\author{
Beriz Čivić $^{1} \&$ Ahmet Sinanagić ${ }^{1}$ \\ ${ }^{1}$ Faculty of Economics, Tuzla University, Bosnia and Herzegovina \\ Correspondence: Beriz Čivić, Ph.D., Assistant Professor, Faculty of Economics, Tuzla University, Bosnia and \\ Herzegovina. E-mail: beriz.civic@untz.ba
}

Received: August 13, 2014

Accepted: August 29, 2014

Online Published: September 5, 2014

doi:10.5430/rwe.v5n2p189

URL: http://dx.doi.org/10.5430/rwe.v5n2p189

\begin{abstract}
The paper explores the presence of certain models of entrance on a foreign market exhibited by furniture exporters from Bosnia and Herzegovina $(\mathrm{BiH})$ and the characteristics of the assortment of their products on a foreign market. It was found that the furniture exporters from $\mathrm{BiH}$ use the dominantly export strategy in internalization of their business. The research results indicate a very low level of usage of more complex marketing strategies of a foreign market appearance, which have higher market potential. Assortment policy is relatively meager along with the non-existence of a broader perception of marketing managers about the need for investing in brand development.
\end{abstract}

Keywords: model of appearance on a foreign market, furniture export, assortment, internalization of business

\section{Introduction}

Existence of economic potential in one country is not per se sufficient. The available economic potentials need to be in the function of country's growth and development. There are numerous examples in the world of the available potentials that are not used in any way or are used insufficiently for the development of economic activities. $\mathrm{BiH}$ is certainly one of these examples. The approach to a more integral and rational usage of available economic resources requires a set of prerequisites. Certainly, some of the most significant ones include identifying available resources, defining the directions of business activity development in the country, and finding the ways how to use the resources in the function of growth and development.

The wood industry is one of the three sectors in $\mathrm{BiH}$ that have a positive balance of payments and it accounts for $11.16 \%$ of the country's total export. The furniture industry has a large share in the total output and export of the wood industry, to both the neighboring as well as the European Union (EU) countries. According to the data of the Foreign Trade Chamber of $\mathrm{BiH}$, the furniture industry in $\mathrm{BiH}$ hires 7,900 workers, which is $5.4 \%$ of the employees in the manufacturing industry. Out of the total number of 183 registered subjects, 29 of them have over 20 employees. In 2004, the furniture export from $\mathrm{BiH}$ was $€ 70,351,522$ (BAM 137,595,618), and it increases from year to year. In 2010, it reached the value of $€ 143,678,448$ (BAM 281,010,619), in percentage $+104.23 \%$. In this interval, the value of furniture export was more than doubled, which shows an extremely high potential of this industry. The most significant export markets are the EU countries, prominent among them being Germany. (Note 1)

Experiences of successful business practice, as well as theoretical findings, show that while internalize their business activities, companies must use marketing strategies of entering a foreign market. The marketing strategy in the performance of companies on a foreign market requires careful and systematic selection of markets, goals, and methods of entering a foreign market and the appropriate management over the marketing mix instruments. In planning and realizing their activities on foreign markets, $\mathrm{BiH}$ furniture exporters need to adhere to the mentioned marketing principles. Successful realization of the marketing concept brings immeasurable and long term benefits to both the company and the exporting country, which is extremely important for the improvement of the entire economic system and achievement of economic welfare of a country.

The process of export recognition in modern market conditions of business includes the transition of the manufacturing or sales concept towards the marketing concept, which is a large limitation for $\mathrm{BiH}$ furniture exporters. The reason is primarily in the limited know-how in the field of international marketing. This paper presents the results of the research into the models of market appearance of $\mathrm{BiH}$ furniture exporters on foreign markets and the characteristics of the assortment that furniture exporters use when they appear on foreign markets. 


\section{Literature Review}

Constant globalization of the world economy and an increasing intensity of the international competition encouraged a large number of national companies to expand their business beyond the border of the home country. (Note 2) When entering a foreign market, a company faces the need to select those strategies that would enable it to use its resources and potentials in the best way possible. The literature presents various classifications of the concepts in international business activities. Therefore, some authors distinguish uninational, multinational, and global concepts. Others divide the concepts into export, plurinational, multinational, multiregional and global. These concepts differ in their goals, meaning the scope of the target market and the level of adaptation of marketing programs to specific markets. The companies that decide to expand their business beyond the national borders have a large number of strategic options at their disposal. One of the classifications distinguishes ownership from nonownership-related modes of entrance to a certain foreign market, where ownership-related modes of entrance include capital investment on a foreign market such as establishing subsidiaries or joint ventures. (Note 3 )

In terms of complexity, we categorize export, cooperative, and investment variants of international business cooperation. Export is a starting but also the most wide-spread strategic variant of international business as it does not expose a company to the effect of large international risks, while financial resources necessary for its realization are acceptable for most internationally oriented companies. In the initial stages of internationalization, companies usually opt for indirect export by using the services of intermediaries on foreign market in order to reduce risk and obligations. This strategy is appropriate for new manufacturers, small and medium enterprises with the limited budget and exposure to foreign market. (Note 4) Once they achieve the initial contact with a foreign market, companies most often decide to use the direct export strategy. (Note 5)

Licensing and franchising are seen as the most popular cooperative variants of international business. Besides them, other cooperative strategies of entering a foreign market worth mentioning are long term manufacturing cooperation, assembly operation, management contracting, contract manufacturing and production sharing. Investments are considered to be the most complex variant of international business and can be realized as international joint venture and independent direct investment abroad. The concept of joint ventures in international business is present into two forms: equity joint ventures and contractual joint ventures. On the other hand, founding one's own company abroad can be realized through the purchase of the existing foreign company (acquisition) and founding a new company (greenfield).

The largest number of national companies in a certain stage of growth and developments want to expand their business to foreign countries. In the initial stages of the internationalization process, these are usually individual exports of temporary output surplus that gradually turn into constant and planned export activities. Regardless of whether the company decides to achieve the domination on one small or smaller segment of the world's market (for example domestic local market, several regional markets) or it has global aspirations, the issue here is the definition of international marketing strategies of market entry. As every strategic decision, the formulation and implementation of international marketing strategy can be seen as the continuous cycle of company's positioning towards constantly changing marketing environment that starts from the business mission, so that the goals could be set on such basis, which the company want to achieve in its international marketing activities. (Note 6)

The behavior of the company on the international market and the ways of strategic decision making are largely conditioned by the basic business and market orientation that the company want to follow in its growth and development beyond the national borders. For decades, in the international marketing four alternative market orientations have been distinguished: ethnocentric, polycentric, regiocentric, and geocentric. (Note 7)

Ethnocentric orientation is characteristic of mainly small and medium enterprises, which do not posses much experience in business activities on a foreign market, or which are at their initial stage of the internationalization process. This orientation is characterized by the application of domestic market marks even in business beyond the national borders. Polycentric orientation is typical of the companies that have some experience in doing business on international markets. It recognizes the specific features of foreign markets where the company appears and includes maximum adaptation to specific demands and needs of these markets. Regiocentric and geocentric orientations integrate individual elements and advantages of both ethnocentric and polycentric orientation. Regiocentric orientation is based on the regional grouping of countries (for example Western Europe, Africa, the Far East etc.). On the other hand, geocentric orientation is a global business philosophy. The selection of any of the given international market orientations is conditioned by a range of factors such as: company's character, international experience, market size, market heterogeneity, and product character.

The modern strategy of entering a foreign market recognizes all manifestations of the international marketing. (Note 8) To the casual eye, the selection of a possible entry should be based on the expected profit. However, the selection of the strategy for entering a foreign market is a part of a complex process of defining and shaping the international 
marketing strategy of a company. Bringing such a decision requires constant monitoring and analyzing a large number of factors. By selecting an appropriate strategy of the appearance on a foreign market, the company defines the framework of business abroad in which it can successfully develop its own possibilities but also expose to various dangers and risks.

The companies with more its own resources and/or those that ensured a better access to other companies' resources through various forms of joining are less limited in selecting foreign market. (Note 9) This also means that such companies have wider possibilities when selecting a strategy for the appearance on a foreign market.

Bringing decisions on a product to export is far more complex then the decisions on the product for the domestic market. All the complexity is reflected in the necessity to search answers to a range of questions such as: (Note 10)

- Which products to use to enter the markets of certain countries?

- Is it necessary to modify the products?

- Whether to appear with a new product?

- Which name of the product to use?

- What type of package to use?

- Which guarantees to offer?

- What kind of post-sale service to provide?

- When to enter a foreign market?

The companies that sell certain products, including furniture, whether for domestic or foreign market, should know that during purchase, a large number of factors affect the customer. These factors can be economic, psychological (motivation, perception, learning, beliefs, and attitudes), social (referential groups, family, role, and statuses), cultural as well as the factors of personal nature.

Generally speaking, we can outline the following characteristics that mostly affect decision making on furniture purchase: (Note 11)

- durability (material and skills used in furniture manufacture, resilience, quality, safety, and guarantee),

- aesthetics,

- trend and fashion,

- functionality (flexibility and multi-practicality),

- utility (comfort, easy to use, easy to clean and maintain),

- $\quad$ economy (price, fitting into the budget);

- harmonization with other objects within the living space, need for the space within the home (convenience for surrounding elements),

- characteristics that show its personal distinctive quality.

Perceiving and ranging these characteristics according to the priority depend on the economic, social, cultural and technological situation of the market where the product is placed. If we observe the influence of the given characteristics of furniture on the process of making decision on purchase, various studies assessed the most significant characteristic of furniture to be its durability, which includes resilience, quality, safety, and guarantee. This can be explained by the fact that modern consumers, regardless of the part of the world they live in, expect a valuable product.

The aesthetic quality of furniture is one of the most dominant characteristics. The appearance of every single furniture item sends a customer a certain message. In cases when price is not the key factor, a person may be led by the personal idea of what is beautiful and aesthetic. Numerous studies defined this factor as one of the three most important when choosing furniture. This factor is important even in economically undeveloped countries. According to a study conducted in Nigeria, where consumers assessed the characteristics of wooden dining furniture, $80.43 \%$ of the subjects mentioned design as an important factor during purchase, while 63.64 outlined the color of the wooden material. (Note 12) In a similar study conducted in Turkey, the subjects rated the aesthetics of furniture as the third most important characteristic during purchase. (Note 13)

When analyzing individual factors, it is possible to conclude that some of them are manifested in a similar way on all the markets, while some are distinctive for every dingle market. For example, economic factors such as standard of life, workers' salary, etc. shall have approximately similar effect on defining priorities in terms of product 
characteristics on developed markets such is the USA but also on the small markets such as $\mathrm{BiH}$. While purchasing a product, lower income customers would pay more attention to its functionality and durability than appearance, whether the market in case is the USA or BiH. Also, higher income customers would have a greater liberty to put more emphasis on aesthetics and actual trends than functionality and durability. However, one should bear in mind the salaries present on a certain market and adapt the element of the marketing mix to the conditions of the given market.

Studies that analyzed this issue in $\mathrm{BiH}$ focus on macroeconomic aspects of the development of furniture industry and the development of business operations of companies in this industry on international markets. However, the microeconomic aspect (especially the marketing aspect) of the business $\mathrm{BiH}$ furniture exporters not specifically analyzed. Such, for example, Foreign Trade Chamber of BiH, in his study The National Export Strategy wood sector, focuses on statistical analysis of certain data related to the summary results of operations exporter of furniture from $\mathrm{BiH}$. Also in study The Chances of BiH industry in 2012-wood and metal processing sector, pointing to specific opportunities and threats at the macroeconomic level faced by exporters of furniture from $\mathrm{BiH}$. However, the development strategy of the company's performance in foreign markets is a complex marketing task. Therefore, this paper is to emphasize specific marketing aspects of business on foreign market and present business model of entry on a foreign market and the characteristics of the assortment offer of furniture exporters from $\mathrm{BiH}$ how would find out the level of development of international marketing for these companies. The focus in this paper is to define the key features of the assortment policy entering a foreign market by $\mathrm{BiH}$ furniture exporters.

\section{Analysis Results and Discussion}

\subsection{Research Methodology}

Aim of the research: To define the key features of the assortment policy entering a foreign market by BiH furniture exporters.

Data collection: The data presented in the following part of the paper are the result of the primary research (field research). They are collected by method of examination (technique of written and verbal structural survey, the form of data collection is the questionnaire). The data were collected from a sample of 20 subjects (exporting furniture companies) selected by convenience sampling. The questionnaire was filled in by top marketing managers in exporting furniture companies. Data collection was executed in the period May-June 2013.

\subsection{Model of Entry on Foreign Market for BiH Furniture Exporters}

The model of entry on a foreign market used by BiH furniture exporters is given in Graph 1. Export is the dominant form of internationalization of $\mathrm{BiH}$ companies. The reason lies in the simplicity of this approach in business internationalization and lack of marketing knowledge for the application of more complex marketing strategies in foreign market appearance. Other reasons are related to lower investment demanded by thus form, when compared to other types of foreign market appearance, and the fact that it bears lower business risks.

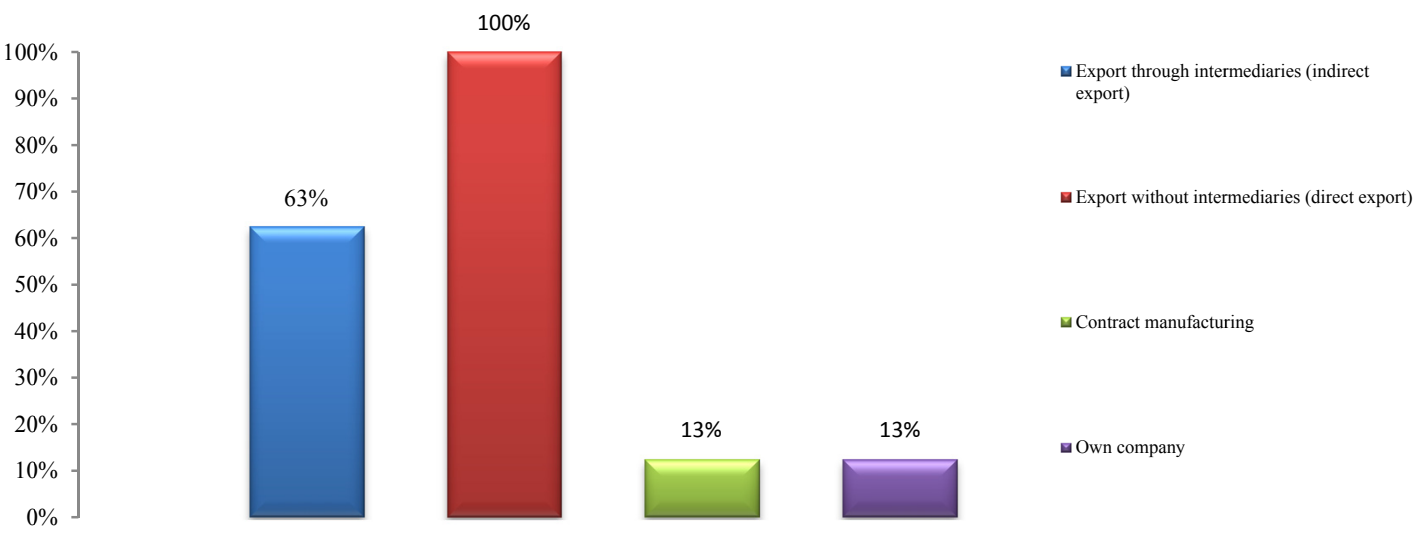

Graph 1. Models of entry on a foreign market used by BiH furniture exporters

Source: Author's research

The research results show that furniture exporters from $\mathrm{BiH}$ implement several models at the same time in their appearance on a foreign market, combining them depending on the specific features of individual markets. Export without intermediaries (direct export) is the most represented model of foreign market appearance and it is used by all the subjects in their appearance on at least one foreign market. The second most important model of 
internationalization is export through intermediaries, i.e. indirect export and it is applied by $63 \%$ of the companies surveyed.

Although export proved to be the most frequent form of foreign market entry for BiH furniture manufacturers, some of them apply other models of appearance on individual foreign markets. For example, $13 \%$ of the subjects perform the tasks of contract manufacturing on a foreign market. This model of business internationalization enables the expanding business without significant capital investment, using low-cost labor force abroad, overcoming local restrictive barriers, keeping control over marketing activities, etc. Besides contractual manufacture, another form of internationalization is the founding of one's own company abroad, as the highest form of internationalization. It is applied by $13 \%$ of the surveyed companies, which is not a rather significant percentage, but it still indicated that there are companies in the furniture industry that achieved more advanced levels of their appearance on a foreign market.

\subsection{Characteristics of Assortment of BiH Furniture Exporters}

The following part of the paper presents the results of the primary research related to the performances of the assortment of $\mathrm{BiH}$ furniture exporters as follows:

- the average value trend of the realized income of the furniture exporters surveyed,

- the trend of the average number of employees for the surveyed furniture exporters,

- the assortment range for the surveyed furniture exporters that they use when appearing on foreign markets,

- the average number of products which the surveyed furniture exports use when appearing on foreign markets, and

- subjects' attitude towards the importance of investing into brand development.

Graph 2 shows the average value of the realized income for the surveyed $\mathrm{BiH}$ furniture exporters in the period from 2008 to 2012. The given data show that the value of income for the surveyed companies dropped in the period from 2008 to 2010, which can somewhat be justified by the large economic crisis that was at its peak at the time.

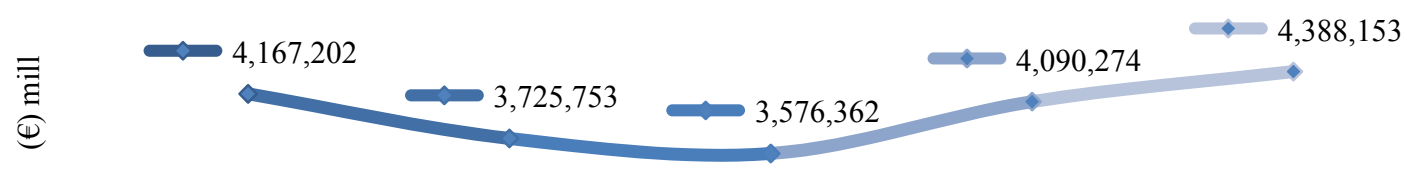

Graph 2. Average value of the total income (in $€$ ) of the surveyed $\mathrm{BiH}$ furniture exporters

Source: Author's research

The situation was stabilized in 2011, when a significant increase of the income values was registered, which continued into 2012, when a record value of app. $€ 4.38$ million was registered. This progress is seen as an encouragement for the upcoming period, since it shoed that $\mathrm{BiH}$ furniture exporters were able to overcome the wave of the crisis and stabilize and improve their business. However, the reasons for the fall of the total income in the years 2009 and 2010 cannot be entirely in the economic crisis, but also in some potential flaws made in the business activities of some furniture exporters, which could have certainly affected such results.

When the average number of subjects' employees is analyzed for the period from 2008 to 2012, the same trend can be noticed as for the value of the total income realized. If the data in Graph 2 and 3 are compared, it is possible to conclude that the fall of the total income value in 2009 and 2010 was followed by a decreased number of employees, which can also be attributed to the large economic crisis that hit the entire world in that period. Income stabilization in 2011 led to the increased number of subjects' employees. This tendency continued in 2012, although the average number of employees is somewhat lower than in 2008. 


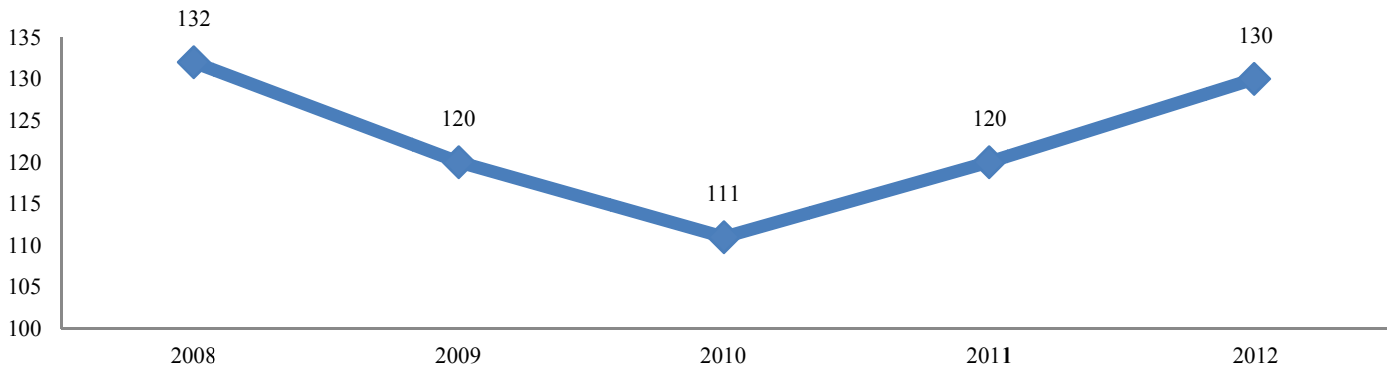

Graph 3. Average number of employees by years for the surveyed $\mathrm{BiH}$ furniture exporters

Source: Author's research

The following parameter that was analyzed within the primary research was the range of assortment, of the number of sales lines that $\mathrm{BiH}$ furniture exporters had in their offer during the last five years. Graph 4 shows that the average number of sales lines that the furniture exporters had in 2008 was five, and that the situation remained unchanged in 2009. Although the year 2010 was characterized by the decrease of the total income and employee number in the furniture industry, it did not have a negative effect on the assortment range. On the contrary, the number of sales lines increased on average by 1, while the growth tendency was registered in 2011 as well, when the average range of assortment included seven products. The situation in 2012 remained unchanged when compared to 2011.
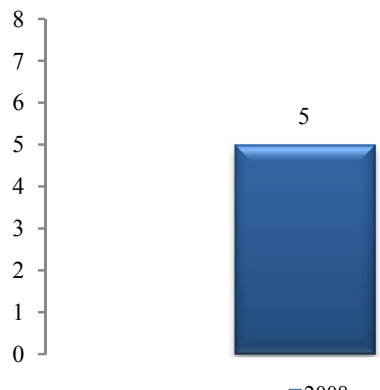

$\square 2008$

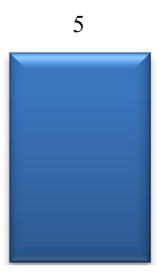

$\square 2009$

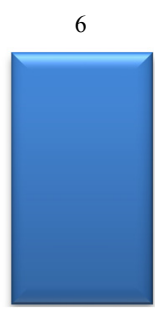

$\square 2010$

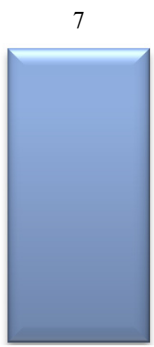

$\square 2011$
7

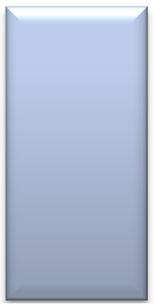

$\square 2012$

Graph 4. Assortment range (the average number of sales lines) for $\mathrm{BiH}$ furniture exporters in the period 2008-2012 Source: Author's research

The EU countries, primarily Germany, Croatia, and Austria, are the most promising markets for BiH furniture exporters, while Serbia is significant among other markets due to its psychological and geographical proximity. Graph 5 shows the number of products which $\mathrm{BiH}$ furniture exporters used when appearing on the key markets. For example, the average number of products which our furniture exporters had on the German market in 2008 was 10 product models, and the number grew up to 18 product models in 2012. A similar situation was on the Austrian market where 9 product models were exported in 2008, reaching the number 17 in 2012.

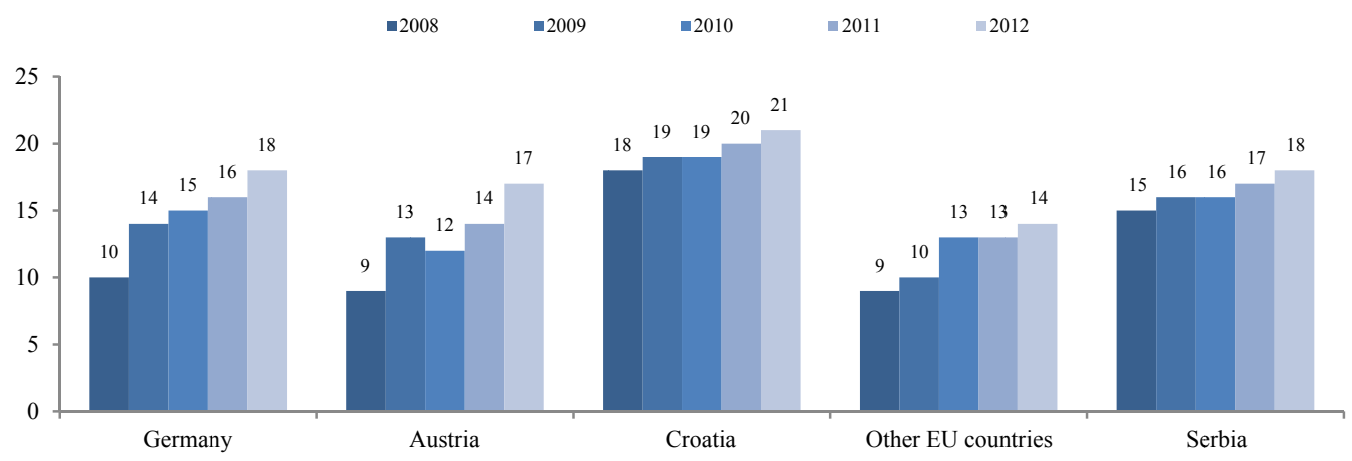

Graph 5. Average number of product models that $\mathrm{BiH}$ furniture exporters use when appearing on individual foreign

Source: Author's research markets 
The markets of Croatia and Serbia are particularly interesting, since these are surrounding countries that BiH share significant cultural and geographical relations. In 2008, there were 18 product models on average, while in Serbia the $\mathrm{BiH}$ furniture industry had 15 product models. Year by year, this number steadily grew, reaching in 2012 on 21 product models on average in Croatia and 18 product models in Serbia.

Brand creation is product (services) enrichment though the creation of mental structures. These structures are aimed to facilitate consumers' decision making during purchase and to provide the company with additional value. A brand helps companies to focus all its marketing activities on the recognizable whole. A brand carries certain safety as it is a guarantee of constant quality that is recognizable on the market. If a brand is managed properly, it can provide a set of intangible values and benefits for consumers and the company itself. Long term insights result into proactive strategies that are created with the aim of strengthening the market value of brand in the situations when consumers face external changes in the marketing environment but also internal changes of company's marketing goals and programs.

As a part of the research, $\mathrm{BiH}$ furniture exporters were given a task to rate, on a 1 to 5 scale (1-absolutely insignificant, 5-absolutely significant) the importance they give to the development of their own brand within their business. The results are presented in Graph 6.

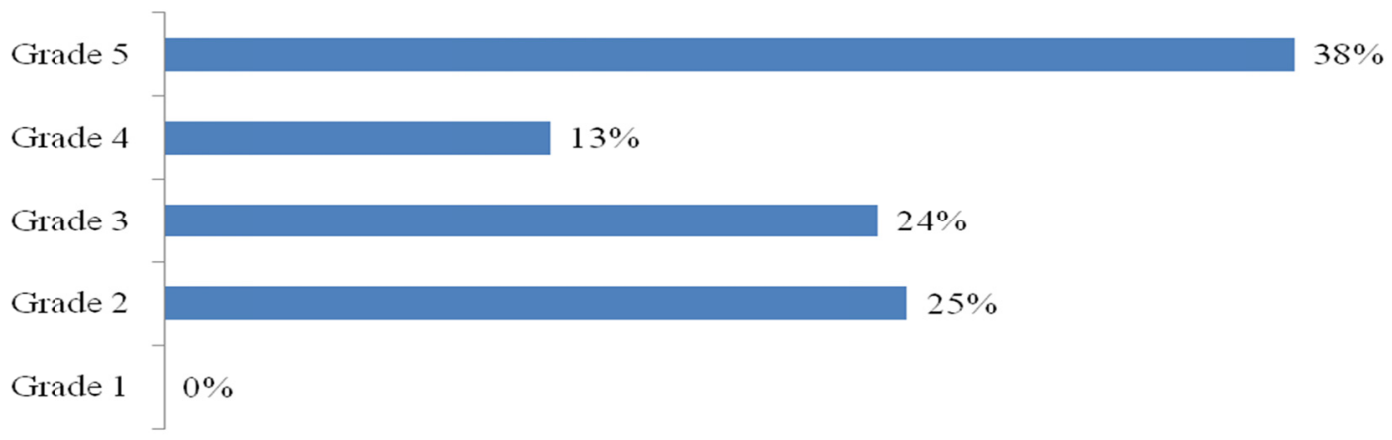

Graph 6. Assessment of importance of investing into brand development for $\mathrm{BiH}$ furniture exporters Source: Author's research

The given results show that $\mathrm{BiH}$ furniture exporters do not recognize the importance of brand development sufficiently and that they do not pay special attention to this issue in their business. Namely, $38 \%$ of the surveyed $\mathrm{BiH}$ furniture exporters rate their significance to investing into brand development with a grade 5. Significance of investing into brand development is somewhat lower for $13 \%$ of the surveyed furniture exporters that rated this business activity with the grade 4 . For $24 \%$ of the subjects this segment of business development has an average importance. The remaining $25 \%$ of the subjects do not see brad development investing as particularly important. However, none of the surveyed companies did not categorically reject the importance of investing into brand development, meaning that none of the companies rated the importance of this business activities with the grade 1 .

\section{Conclusion}

\subsection{Summary of Findings}

The total export of furniture from $\mathrm{BiH}$ in the last five years was $€ 1.66$ billion (BAM 3.25 billion), out of which $98 \%$ account for the market of European countries and the EU countries in particular. Regarding the importance of furniture export for the $\mathrm{BiH}$ economy, it was rather important to examine the market performances of our exporters.

The value of total income realized by furniture exporters varied in the last five years. Thus, in 2009 and 2010 it registered a fall, while in the years that followed a significant increase of income was evident. The reasons for the fluctuation can be searched in the global economic crisis that was at it peak in the given period. This is supported by the fact that in the given period the number of employees reduced at the companies that export furniture.

What needs to be particularly emphasized is a relatively limited number of sales lines that BiH furniture exporters use when appearing on a foreign market. In the observed period, a significant trend of assortment range increase was not registered. It is encouraging that the number of products that $\mathrm{BiH}$ furniture exporters use when appearing on the foreign markets slightly increases. However, it is very concerning that a large number of top managers of furniture exporters attach little importance to investing into the development of their own brands.

The dominant model of appearance on a foreign market, used by $\mathrm{BiH}$ furniture exporters, is direct export, while over 
$50 \%$ of the exporters combine it with indirect export, depending on the foreign market. Other models such as contractual manufacture and one's own company abroad are not present to a larger extent. This can serve for the conclusion that $\mathrm{BiH}$ companies in the furniture industry are still positioned rather low at the evolutionary scale in the internationalization of their business. In order to overcome this, they need to start an urgent systematic and continuous transfer of marketing know-how into the business practice of $\mathrm{BiH}$ furniture exporters so that the management of these companies could develop their competitiveness on the extremely demanding international furniture market.

\subsection{Limitations Research}

The research results answers on many questions and have generated some interesting facts. However, there are some limitations on the scope of research both in terms of number of subjects (exporting furniture companies) and in terms of geographical limitations to only one country $(\mathrm{BiH})$. First of all, the research of a larger sample that would include the companies from region would give some deeper insights into level of development of international marketing strategies of companies in furniture industry and these performances on international markets.

\subsection{Recommendations for Further Research}

Future research should focus on deeper analysis of the level of development in certain aspects of marketing management in $\mathrm{BiH}$ companies in the furniture industry. It is necessary to determine in what way could be transfer quality marketing knowledge that would enable the managers of these companies to create better production and sales portfolio and improve its strategy of internationalization of business. Key areas that require further research are related to: the segmentation of foreign markets, marketing research of consumers' needs and habits in international markets and development integrated marketing strategies for international markets.

\section{References}

Arowosoge O., \& Tee N. (2010). Evaluation of consumers' choice of wooden dining furniture in Southwestern Nigeria: A market strategy for furniture manufacturers and marketers. African Journal of Biotechnology, 9.

Cateora P. R., \& Graham J. L. (2002). International Marketing. McGraw-Hill, New York

Cavusgil S. T., Knight G., \& Reisenberger J. R. (2012). International Business. Prentice Hall, New Yersey.

Foreign Trade Chamber of Bosnia and Herzegovina. Izvozna strategija drvnog sektora. Retrieved June, 2014, from http://komorabih.ba/wp-content/uploads/2013/06/bhepa-izvozna-strategija-drvnog-sektora.pdf

Fostering interventions for market advancement-FIRMA. (2012). Izgledi BiH industrije u 2012. godini-drvni i metaloprerađivački sektor, USAID \& Sweden. Retrieved June, 2014, from www.firmaproject.ba

Hollensen S. (2011). Global Marketing: A Decision-Oriented Approach. Prentice Hall, New Yersey.

Jain S. C. (1990). International Marketing Management. PWS - Kent P. C. Boston, Massachusets.

Jović M. (1997). Međunarodni marketing: Od izvoznog ka globalnom konceptu. TrimSoft Trade, Beograd.

Koch A. J. (2001). Factors influencing market and entry mode selection: developing the MEMS model. Marketing Intelligence \& Planning, 19/5.

Küster I., \& Vila N. (2011). The market orientation-innovation-success relationship: The role of internationalization strategy. Innovation: Management, Policy \& Practice, 13(1).

Leonidou L. C., Palihawadana D., \& Theodosiou M. (2011). National Export-Promotion Programs as Drivers of Organizational Resources and Capabilities: Effects on Strategy, Competitive Advantage, and Performance. Journal of International Marketing, American Marketing Association, 19(2).

Mihailova I., \& Panibratov A. (2012). Determinants of International Strategies of Emerging Market Firms: A Multilevel Approach. Journal of East-West Business, 18.

Morgan N. A., Katsikeas C. S., \& Vorhies D. W. (2012). Export marketing strategy implementation, export marketing capabilities, and export venture performance. Journal of the Academy of Marketing Science, 40(2).

Navarro A. \& Co. (2011). Antecedents and Consequences of Firms' Export Commitment: An Empirical Study. Journal of International Marketing, American Marketing Association, 18(3).

Oztop H., Erkal S., \& Gunay G. (2008). Factors Influential in Consumer's Furniture Selection and their Preferences regarding Product Features. The International Journal of Interdisciplinary social sciences, 3(6).

Previšić J., \& Ozretić Došen Đ. (1999). Međunarodni marketing. Masmedia, Zagreb.

Rakita B. (2009). Međunarodni marketing: Od lokalne do globalne perspective. CID Ekonomskog fakulteta u 
Beogradu, Beograd.

Ramsey J. R., \& Bahia B. R. (2013). How to Determine Subsidiary Performance Based on the Internationalization Strategy. Journal of Management Policy and Pratice, 14(1).

Root F. R. (1994). Entry Strategies For International Markets. Jossey-Bass.

Sadaghiani J. S., Dehghan N. A., \& Zand K. N. (2011). Impact of International Market Entry Strategy on Export Performance. The Journal of Mathematics and Computer Science, 3(1).

Sanyal R. N. (2001). International Management: A Strategic Perspective. Prentice-Hall, New Yersey.

Shahrul N., Bin N., \& Nor M. (2011). Factors Influencing Export Intermediaries' Competitive Strategies and Performance: A Conceptual Paper. Journal of Marketing Development and Competitiveness, 5(4).

Sinanagić M. (2008). Strategijske varijante ulaska na inostrano tržište. Gama-X Brčko, Brčko.

Terpstra V., \& Sarathy R. (2001). International Marketing ( $8^{\text {th }}$ ed.). Chicago IL, Dryden Press.

Tsai H.C., \& Eisingerich A. B. (2010). Internationalization Strategies of Emerging Markets Firms. California Management Review, 53(1).

\section{Notes}

Note 1. Foreign Trade Chamber of Bosnia and Herzegovina, Izvozna strategija drvnog sektora, http://komorabih.ba/wp-content/uploads/2013/06/bhepa-izvozna-strategija-drvnog-sektora.pdf (accessed: June, 2014), p. 9.

Note 2. Morgan N. A., Katsikeas C. S., Vorhies D. W., (2012), Export marketing strategy implementation, export marketing capabilities, and export venture performance, Journal of the Academy of Marketing Science, Volume 40, Issue 2, p. 271.

Note 3. Sadaghiani J. S., Dehghan N. A., Zand K. N., (2011), Impact of International Market Entry Strategy on Export Performance, The Journal of Mathematics and Computer Science Vol .3, No.1, p. 55.

Note 4. Shahrul N., Bin N., Nor M., (2011), Factors Influencing Export Intermediaries' Competitive Strategies and Performance: A Conceptual Paper, Journal of Marketing Development and Competitiveness, Vol. 5, No. 4, p. 145.

Note 5. Küster I., Vila N., (2011), The market orientation-innovation-success relationship: The role of internationalization strategy, Innovation: Management, Policy \& Practice, Volume 13, Issue 1, p. 37.

Note 6. Jović M., (1997), Međunarodni marketing: Od izvoznog ka globalnom konceptu, TrimSoft Trade, Beograd, pp. 300-301.

Note 7. Rakita B., (2009), Međunarodni marketing: od lokalne do globalne perspektive, CID Ekonomskog fakulteta u Beogradu, Beograd, p. 22.

Note 8. Sinanagić M., (2008), Strategijske varijante ulaska na inostrano tržište, Gama-X Brčko, Brčko, p. 16.

Note 9. Koch A.J., (2001), Factors influencing market and entry mode selection: developing the MEMS model, Marketing Intelligence \& Planning 19/5, p. 354.

Note 10. Jain S. C. (1990), International Marketing Management, PWS - Kent P. C. Boston, Massachusets, p. 382.

Note 11. Oztop H., Erkal S., Gunay G., (2008), Factors Influential in Consumer's Furniture Selection and their Preferences regarding Product Features, The International Journal of Interdisciplinary social sciences, Vol. 3, No. 6, p. 26.

Note 12. Arowosoge O., Tee N., (2010), Evaluation of consumers' choice of wooden dining furniture in Southwestern Nigeria: A market strategy for furniture manufacturers and marketers, African Journal of Biotechnology, Vol. 9, p. 3112.

Note 13. Oztop H., Erkal S., Gunay G., op. cit., p. 29. 